\title{
TOMM20 wt Allele
}

National Cancer Institute

\section{Source}

National Cancer Institute. TOMM20 wt Allele. NCI Thesaurus. Code C118208.

Human TOMM20 wild-type allele is located in the vicinity of $1 \mathrm{q} 42$ and is approximately 20

$\mathrm{kb}$ in length. This allele, which encodes mitochondrial import receptor subunit TOM20

homolog protein, is involved in transporting proteins from the cytosol into the

mitochondrion. 